\title{
Improvement on small-scale tuna fisheries data quality through the Application of e-Logbook System
}

\author{
Syahril Abd Raup ${ }^{1,2^{*}}$, Sri Patmiarsih ${ }^{2}$, Rista Devi Juniar ${ }^{2}$, and Bram Setyadji ${ }^{3}$ \\ ${ }^{1}$ Postgraduate student, Coastal and Ocean Resources Management Study Program, Faculty of Fisheries and Marine, IPB University. \\ J1. Raya Dramaga, Kampus IPB Dramaga, Bogor, West Java, Indonesia - 16680. \\ ${ }^{2}$ Directorate of Fish Resources Management, Directorate General of Capture Fisheries, Ministry of Marine Affairs and Fisheries. \\ Mina Bahari Building II, 14th Floor, Jl. Medan Merdeka Timur No.16, Jakarta, Indonesia - 10110. \\ ${ }^{3}$ Research Institute for Tuna Fisheries, Agency for Marine and Fisheries Research and Human Resources, Ministry of Marine \\ Affairs and Fisheries. Jl. Mertasari No. 140, Sidakarya, Denpasar, Bali, Indonesia - 80224.
}

\begin{abstract}
Tuna and tuna-like fisheries play a vital role in Indonesian livelihood, especially in the archipelagic waters. However, despite the importance, the concern in general data collection activities for tuna, i.e., limited, with incomplete scientific knowledge and insufficient data has hampered the assessment. The purpose of this study was to analyse on how fisheries-dependent data system could transform the data quality. For this purpose, the analysis was conducted based on e-logbook data from January to December 2020. The result showed that some robust fisheries indicators (catch, effort, fleet and species composition) could be produced from this particular dataset. In addition, e-logbook has the best attribute for improving the data quality, especially for small-scale tuna fisheries in FMA-714. Low cost and vast spatial and temporal coverage are the main characteristics on why the program should be expanded and monitored carefully in the future.
\end{abstract}

\section{Introduction}

Tuna and tuna-like fisheries play a vital role in Indonesian livelihood [1,2]. Among eleven Fisheries Management Area (FMA), at least nine are touted to be the migration areas and potential fishing ground for tunas [3-8]. The biggest challenge in managing the fisheries was the fact that more than $80 \%$ are determined as small-scale fisheries (incl. subsidiary and indigenous fishing) $[9,10]$, and widely distributed in the coastal and archipelagic waters.

Two-third of the tuna catch in Indonesian EEZ (Economic Exclusive Zone) is contributed from archipelagic waters, especially from FMA-713, FMA714, and FMA-715 [1]. Banda Sea and its adjacent waters is a trajectory of the water mass from the Pacific Ocean to the Indian Ocean [11]. The characteristics and dynamics of the waters are strongly influenced by the topography and configuration of existing islands and the monsoon wind that occurs in the region [12]. The existence of upwelling phenomena causes this region to be rich in potential fish resources, including tuna and skipjack [13]. In addition, it also acted as a nursery ground and spawning area for tunas and other large pelagic fishes [14].

Based on Ministerial Decree No. 50/KEPMEN$\mathrm{KP} / 2017$, total estimated biomass (non-tuna) in FMA713, FMA-714, and FMA-715 was about 3 million ton, whereas the average production of main tuna species (yellowfin, bigeye and skipjack tuna) from 2005-2012 in FMA-714 was around 230,000 MT. Despite of its potential, no specific management measure applied into this area, apart from Ministerial Regulati* on No. 4/PERMEN-KP/2015 related to open-close system. This drives the necessity for conducting harvest strategy as the foundation for sustainability. Hoshino et al. [15] started a pilot project in 2020 for assessing yellowfin and skipjack tuna. Although an interim harvest strategy has been adopted, but the key uncertainties i.e., abundance indices and effective sample size still need to be improved in order to get a more robust analysis.

Prior to the assessment, some reports $[16,17]$ expressed the concern in general data collection activities for tuna, especially before 2010, which labelled as limited, with incomplete scientific knowledge and insufficient data, hence could not be generated to produce an accurate assessment. Even though the data after 2010 was available, but the scarcity i.e., lack of temporal and spatial consistencies combined with various data formats have hampered the analysis [18]. The issue was intercepted by the Directorate General of Capture Fisheries (DGCF) by promoting elogbook system since 2018. The purpose of this study was to analyse on how e-logbook system could transform the data quality for small-scale tuna fisheries in Indonesian archipelagic waters. The assessment also covers how to use the information to generate spatial and temporal fisheries indicators. Hopefully, the result can be used as further development of e-logbook system for encouraging sustainability in the future.

\footnotetext{
*Corresponding author: chaliarrauf@yahoo.com
} 


\section{Materials and Methods}

\subsection{Data source}

The primary data was obtained from Integrated Logbook Information System (SILOPI) restricted only within Fisheries Management Area (FMA) 714 between January to December 2020, courtesy of Directorate General of Capture Fisheries. Prior to extraction, the logbook data has been scrutinized by the verificatory officers by consider following rules, i.e., conformity of fishing ground, gear and type of species landed; suitability between total catch reported and landed; compatibility between the catch reported related to the fishing capacity of each vessel; confirmation of departure and landing port as mentioned in the license.

\subsection{Data cleaning and validation}

Ensuring a robust analysis, data cleaning and filtering were conducted prior to analysis. This was necessary, largely purposed to clear any potential inconsistencies and typos, which commonly found in logbook data [19]. In principle the process was commenced as follows, i.e., setting must be commenced between the departure and the arrival date; the number of day-at-sea should be the differential between the arrival and the departure date; total sets per landing should be at least $50 \%$ of the total day-at-sea; georeferenced points should not intersect with the land nor excess the boundaries from the area of interest.

As a result, a total of 6,388 set by set e-logbook data were successfully generated, which consist of 297 vessels across six tuna-related gears, i.e., lift net, hand line, pole and line, purse seine, longline and troll line (Table 1).

Table 1. Summary of dataset used for analysis.

\begin{tabular}{|c|c|c|}
\hline Declared Gears & No. Boats & Total Sets \\
\hline Lift net & 11 & 452 \\
\hline Hand line & 39 & 401 \\
\hline Pole and line & 9 & 140 \\
\hline Purse seine & 204 & 4,639 \\
\hline Longline & 4 & 89 \\
\hline Troll line & 30 & 667 \\
\hline Total & 297 & 6,388 \\
\hline
\end{tabular}

\subsection{Data Analysis}

A number of indicators will be analysed in this study, including:

1. Catch composition by gear by dominant group species. The result will be juxtaposed with Ministerial Regulation No. 86/2016 for conformity study, whether its still relevance as to date.

2. Catch composition of non-target species (by-catch)

3. Effort distribution by gear, to see any overlapping between gear operations

4. Monthly trend of catch per unit of effort (CPUE), whereas for longline declared in $\mathrm{kg} / 1000$ hooks
[20] and the rest are in $\mathrm{kg} / \mathrm{day}$, assuming at least one set is commenced per day.

All statistical analysis were conducted using Microsoft Excel and $\mathrm{R}$ version 4.0.5 [21], while mapping was constructed under QGIS version 3.18 [22].

\section{Results and Discussions}

\subsection{E-Logbook implementation}

The first version of e-logbook [23-26] was introduced on August 2015 by the Marine and Fisheries Technology Research and Engineering Center (P3TKP), however it didn't fully materialized due to complication in production and installation the hardware into the fishing vessels. Therefore, a more user friendly and android-based e-logbook app (software) was launched in 2018, in parallel with Our Ocean Conference (OOC) event, held in Bali. The app supposedly working with (online) or without (offline) internet connection, thus the new platform is more convenient to use and free of charge, as more than two-third ( 200 millions) of Indonesian population capable of accessing internet and smartphones [27]. It also could reach a more diverse community.

Since the introduction, the activation reaches 12,000 nationwide users by April 2021, whereas for fleets operating in the FMA (Fisheries Management Area) 714 also increasing with a total 164 boats until August, 2021 (Figure 1). The vast adoption was largely due to massive socialization throughout the years. However, since a lot of individual landing sites in eastern part of Indonesia, the implementation was slightly disturbed because elogbook requires authorization from harbourmaster (port inspector). Hence, the activation was limited only for vessels based on official ports. As a result, only 304 boats reported the e-logbook in 2020, a considerably very low compared to the number of national activations at the same period. A possible online request for activation should be prioritized for future development to address the lingering issue.

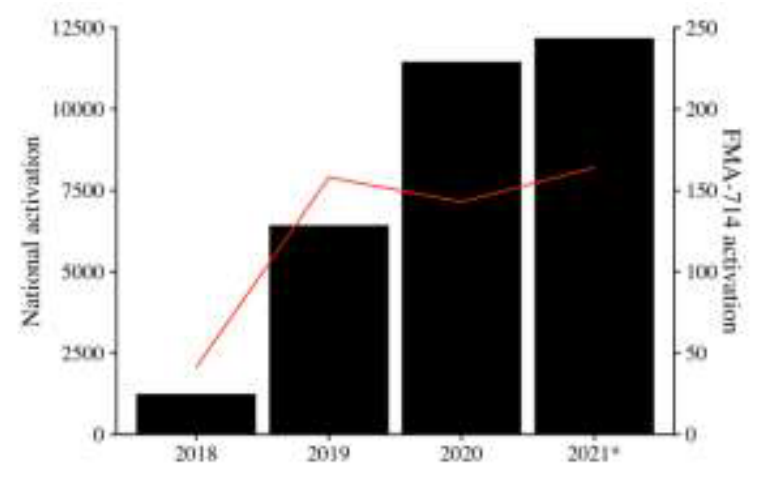

Fig. 1. Number of e-logbook activation for national (bar) and specific FMA-714 area (line) from November, 2018 to August, 2021 (Remarks: Modified from Directorate General of Capture Fisheries/DGCF) 


\subsection{E-logbook for data improvement on small- scale fisheries}

Most of the data available for determining the stock status of the fisheries in FMA-714 were from port monitoring programs $[15,18,28]$. However, such data requires a lot of investment, especially in human resources (enumerator), securing fund for their wage bills and other expenses. It was inevitable because manual logbook dataset was unreliable at that moment. This is where e-logbook could be a workaround, since it's specifically designed with color-coded menu which intended to be operated even with illiterate fishermen. It also compiled with some picture of dominant fish species, while fishing location, time and duration are automatically generated. Improvements on data quality can be assessed through some of these indicators as follows:

\subsubsection{Fleet composition}

Purse seine was the dominant fishing gear used in FMA714. It comprised almost two-third of the total reported fleet, followed by hand line and troll line, which both contributed at least a quarter and a small portion of lift net, pole and line and longline (Figure 2). This composition aligned with previous studies in the Banda Sea for the last 10 years [29-31]. The gear mainly targeting either small pelagic fishes or tuna and tuna-like species, regardless whether it licensed for the first or later [32]. Hence, a more considerate arrangement is needed in order to encourage the sustainability in the area.

Since there was an indication of the area to be the spawning ground for tunas, a numerous regulations have been issued to control the fishing activity, particularly within FMA-714, such as: Ministry of Marine Affairs and Fisheries Regulation No. 4/PERMEN-KP/2015 on open and close system policy, No. 47/PERMEN$\mathrm{KP} / 2016$ on definition of conservation area and No. 47/PERMEN-KP/2016 on moratorium of fishing permit, especially for ex-foreign vessels.

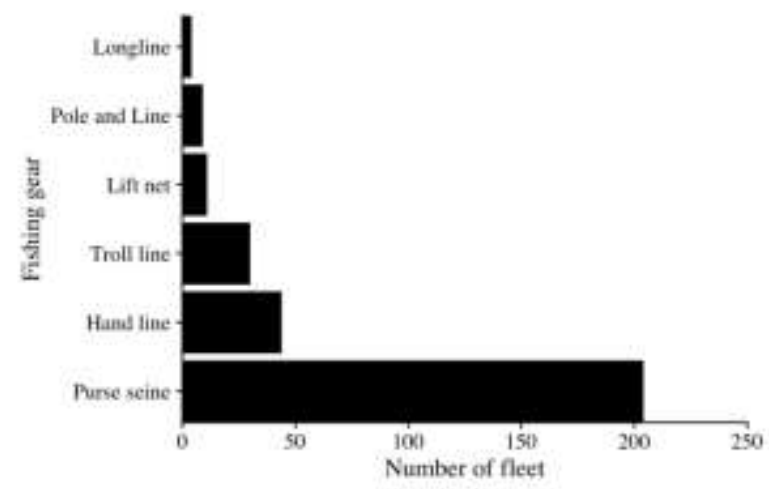

Fig. 2. Composition of fleet reporting e-logbook under FMA714 in 2020.

\subsubsection{Catch composition}

The catch composition for most of the fleet operating in the FMA-714 are dominated $(>75 \%)$ by tropical tuna species (i.e., yellowfin, bigeye and skipjack tuna), except for lift net and purse seine which mainly targeting small pelagic, neritic tuna and demersal fishes (Figure 3 ). The result on purse seine fleet was slightly different compared to previous study from Hariati [31] which the proportion of small pelagic to large pelagic was 1:3.

We consider the e-logbook data provide a better picture on the fisheries rather than the data generated from landing sites. Because most of purse seiners are known to target either small pelagic fishes (scads) $[33,34]$ or skipjack tuna [35] in a balanced proportion. As for other gears, the result were relatively similar with previous findings [36-41]. A further prove that elogbook data was reliable for catch composition analysis, which is a valuable information for estimating total biomass under data limited situation.

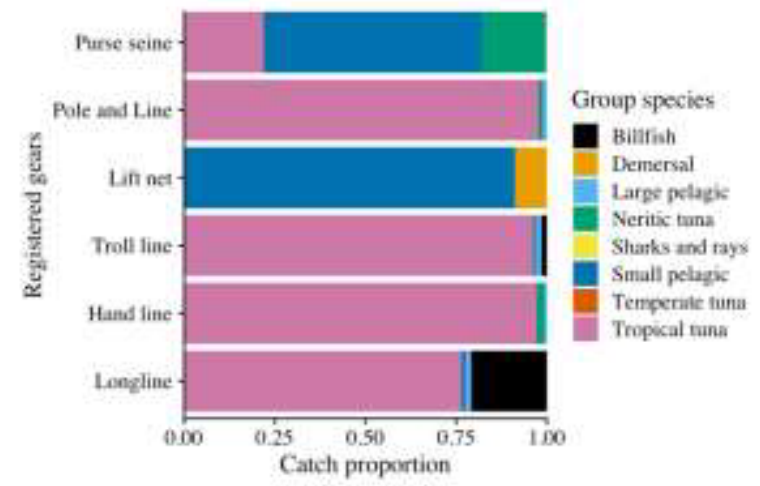

Fig. 3. Catch composition by gear operating in the FMA-714.

\subsubsection{Effort distribution}

The main competitive advantage of e-logbook data was the deliverance of accurate spatial information when reported accordingly. Figure 4 beautifully depicts the characteristic of fishing location for each gear. Hand line, pole and line lift net and purse seine has overlapping fishing ground, whereas longline and troll line, each has distinct preferences. Before the implementation of logbook, spatial information was mainly collected through interview [31], satellite utilization, such as: visible infrared imaging radiometer suite (VIIRS) boat detections (VBD) with vessel monitoring system (VMS) [42], and other hardware implant on the fishing vessels, e.g., spot trace [43].

However, the first approach was considerably has less robust, as fishermen are reluctant to be interviewed nor gave their fishing locations. On the other hand, deployment of VMS only mandatory for vessel above 30 GT [44] and spot trace require financial support for installing and implementation. Hence, e-logbook is a less cost solution for national spatial fisheries data collection system. Development and monitoring on this system should be the first priority for government, nongovernmental organization (NGO) and other fisheries stakeholders.

\subsubsection{Catch per unit of effort (CPUE)}

Abundance indices, such as: catch per unit of effort (CPUE) is an important variable for relaying the current condition of stock in specific fishery [45] and very useful for running model on more detailed stock 
assessment [46]. Ideally, the indices are produced from fisheries-dependent data (e.g., fisheries surveys, scientific observer), however, such approach are costly, therefore most studies are exploring the port monitoring data for achieving the goal.
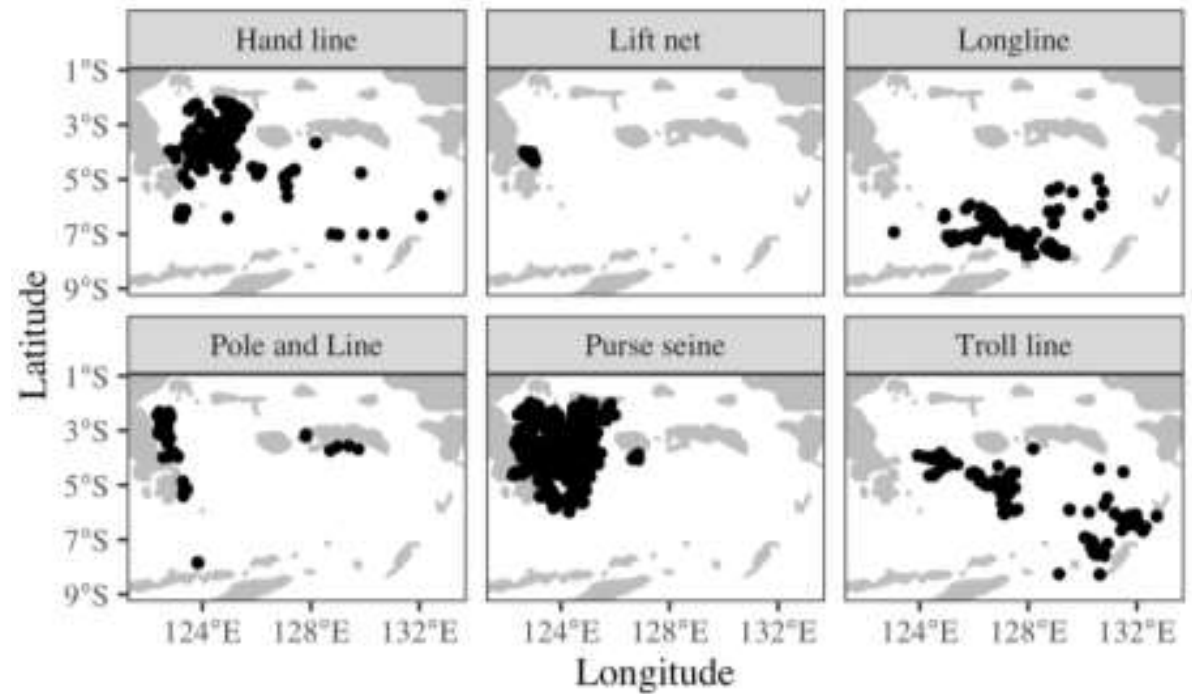

Fig. 4. Effort distribution of fishing gears operating in FMA-714 based on e-logbook information.

Since most the landing sites in FMA-714 are widespread across small islands and private jetties, enumeration can only be possibly conducted in ports or big landing sites. By utilizing e-logbook, such obstacles can be limited and the CPUE analysis can be performed either with spatial or temporal situation. Figure 5 depicts the mean monthly CPUE for main tuna species, i.e., yellowfin and skipjack tuna.

The trends showed that the fishing season for these two particular species are different, depend on the gear used. Third quarter was the peak season for handline, while catch rate from purse seine relatively stable over months, between longline and troll line performed opposite trends.

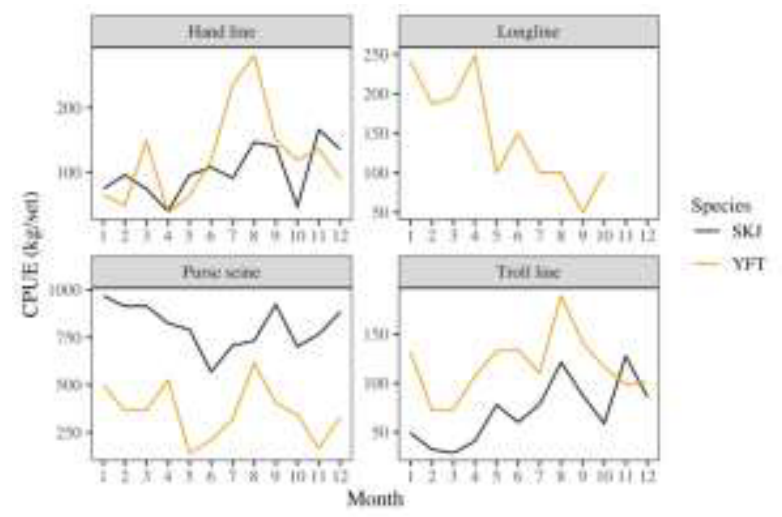

Fig. 5. CPUE of main tuna species by gear registered in FMA714 based on e-logbook information.

Not every tuna species could be analysed due to scarcity of some data. However, if the result was crossreferenced with the available publications, they have produced similar result. For example, the fishing intensity of hand line fishery was accumulated during June to August, which was aligned with a previous studies from Enjah [41] and Nelwan et al. [47]. Moreover for purse seine and troll line fisheries which match with study from Widodo and Nugraha [29]. Interestingly, there was no publication about the monthly catch rate for longline, probably due to difficulties in collecting the data. This is where elogbook data could be the right tools for improving the data quality by filling the missing information.

The key to this improvement lies on how the elogbook could be expanded and maintained for years to come. Law enforcement is necessary but build an understanding to fishermen about the importance on filling and reporting the e-logbook should be the priority for the stakeholders. When proper data could be established then the analysis could be carried on, especially for harvest strategy in this particular area.

\section{Conclusion}

E-logbook has the best attribute for improving the data quality, especially for small-scale tuna fisheries in FMA-714. Low cost and vast spatial and temporal coverage are the main characteristics on why the program should be expanded and monitored carefully. Analysis on fisheries indicators showed a promising result, especially for filling the gap which could not be covered by research.

Acknowledgement. The authors would like extend their great appreciation to the Directorate of Fish Resource Management, Directorate General of Capture Fisheries for permission to access fisheries e-logbook data. Syahril Abd.Raup, Sri Patmiarsih, Rista Devi Juniar and Bram Setyadji are the main contributors to this scientific paper.

\section{References}

1. F. Satria, L. Sadiyah, A. A. Widodo, C. Wilcox, J. H. Ford, and B. D. Hardesty, Marine Policy 95, 8 (2018)

2. D. E. Duggan and M. Kochen, Marine Policy 67, 30 (2016)

3. N. Akbar, N. P. Zamani, and H. H. Madduppa, Depik 3, 65 (2014) 
4. P. D. Pertiwi, A. Sembiring, A. Mahardini, D Cahyani, A. Wahyu, B. Nugraha, R. Kartika Sulistyaningsih, I. Jatmiko, and I. Mahardika, in (2014)

5. D. Al Malik, N. P. D. Pertiwi, A. Sembiring, N. L. A. Yusmalinda, E. Y. Ningsih, and I. A. Astarini, Biodiversitas Journal of Biological Diversity 21, 3637 (2020)

6. I. A. Astarini, S. A. Ardiana, I. N. G. Putra, P. D. Pertiwi, A. Sembiring, A. Yusmalinda, and D. Al Malik, Musamus Fisheries and Marine Journal 3, 107 (2021)

7. B. R. Moore, P. Lestari, S. C. Cutmore, C. Proctor, and R. J. G. Lester, ICES Journal of Marine Science 76, 1678 (2019)

8. P. Lestari, R. J. G. Lester, and C. Proctor, Indonesian Fisheries Research Journal 23, 23 (2017)

9. N. Ayunda, M. R. Sapota, and A. Pawelec, in Interdisciplinary Approaches for Sustainable Development Goals, edited by T. Zielinski, I. Sagan, and W. Surosz (Springer International Publishing, Cham, 2018), pp. 147-167

10. DJPT, Statistik Perikanan Tangkap Indonesia Menurut Provinsi, 2016 (Direktorat Jenderal Perikanan Tangkap, Indonesia, 2017)

11. I. M. Radjawane and P. P. Hadipoetranto, Ilmu Dan Teknologi Kelautan Tropis 6, 525 (2015)

12. W. E. Rintaka and E. Susilo, in IOP Conference Series: Earth and Environmental Science (IOP Publishing, Batu, Malang, Indonesia, 2018), p. 012041

13. H. A. Rachman, J. L. Gaol, F. Syamsudin, and A. As-syakur, in IOP Conference Series: Earth and Environmental Science (IOP Publishing, Bogor, Indonesia, 2020), p. 012015

14. Z. Nasution, K. Amri, T. Arifin, W. S. Pranowo, J. Haryadi, S. Wibowo, A. Zulham, U. Mu'awanah, S. Syamdidi, R. B. A. Nugraha, B. Sumiono, and E. Erlania, Potensi Sumber Daya Kelautan Dan Perikanan WPPNRI 714

(Amafradpress - Badan Penelitian dan

Pengembangan Kelautan dan Perikanan Kementerian Kelautan dan Perikanan, Jakarta, 2016)

15. E. Hoshino, R. Hillary, C. Davies, F. Satria, L. Sadiyah, T. Ernawati, and C. Proctor, Fisheries Research 227, 105539 (2020)

16. R. Gillett, West Pacific East Asia Oceanic Fisheries Management (Western and Central Pacific Fisheries Commission (WCPFC), Pohnpei, Federated States of Micronesia, 2013)

17. S. Yuniarta, P. A. van Zwieten, R. A. Groeneveld, S. H. Wisudo, and E. C. Van Ierland, Fisheries Research 193, 173 (2017)

18. F. Satria and L. Sadiyah, Ind. Fish. Res. J. 24, 39 (2018)

19. D. B. Sampson, Fisheries Research 112, 59 (2011)

20. R. Coelho, P. G. Lino, and D. Rosa, Paper Presented on 15th Working Party on Billfish, San Sebastian, Spain, 10-14 September 2017, IOTC-2017-WPB15-14 17 (2017)
21. R Core Team, R: A Language and Environment for Statistical Computing (R Foundation for Statistical Computing, Vienna, Austria, 2020)

22. Q. D. Team, QGIS Geographic Information System (Open Source Geospatial Foundation Project, 2020)

23. H. Nugroho and A. Sufyan, Jurnal Kelautan Nasional 9, 93 (2014)

24. H. Nugroho, A. Sufyan, and R. Akhwady, Jurnal Kelautan Nasional 8, 101 (2013)

25. H. Nugroho, A. Darmawan, and A. Sufyan, Jurnal Kelautan Nasional 11, 53 (2016)

26. H. Nugroho, A. Sufyan, and N. N. Wiadnyana, Jurnal Kelautan Nasional 10, 113 (2017)

27. Tim APJII, Buletin APJII 74, 10 (2020)

28. N. R. Loneragan, B. Wiryawan, A. R. Hordyk, A. Halim, C. Proctor, F. Satria, and I. Yulianto, in Proceedings from Workshops on Management Strategy Evaluation of Data-Limited Fisheries: Towards Sustainability - Applying the Method Evaluation and Risk Assessment Tool to Seven Indonesian Fisheries, edited by N. R. Loneragan, B. Wiryawan, A. R. Hordyk, A. Halim, C. Proctor, F. Satria, and I. Yulianto (Murdoch University, Western Australia, and IPB University, Indonesia, 2021), pp. 11-27

29. A. A. Widodo and B. Nugraha, BAWAL Widya Riset Perikanan Tangkap 2, 299 (2017)

30. A. A. Widodo, R. T. Mahulette, and F. Satria, Jurnal Kebijakan Perikanan Indonesia 7, 45 (2015)

31. T. Hariati, Jurnal Penelitian Perikanan Indonesia 17, 139 (2016)

32. U. Chodrijah and B. Setyadji, Indonesian Journal of Marine Sciences/Ilmu Kelautan 23, 171 (2018)

33. H. Hufiadi and E. Nurdin, Jurnal Penelitian Perikanan Indonesia 19, 39 (2016)

34. A. Mahmud and R. L. Bubun, Jurnal Teknologi Perikanan Dan Kelautan 6, 159 (2015)

35. W. Waileruny, E. S. Wiyono, S. H. Wisudo, T. W. Nuraini, and A. Purbayanto, in Prosiding Simposium Pengelolaan Perikanan Tuna Berkelanjutan (WWF \& KKP, Bali, Indonesia, 2015), p. 1238

36. A. Assir, M. Palo, and R. K. Sari, Jurnal IPTEKS Pemanfaatan Sumberdaya Perikanan 4, 108 (2017)

37. B. Nugraha and S. Mardlijah, BAWAL Widya Riset Perikanan Tangkap 2, 45 (2017)

38. E. Rahmat and M. F. Yahya, Buletin Teknik Litkayasa Sumber Daya Dan Penangkapan 13, 119 (2016)

39. U. Chodrijah and B. Nugraha, Jurnal Penelitian Perikanan Indonesia 19, 9 (2013)

40. T. Hidayat, U. Chodrijah, and T. Noegroho, Jurnal Penelitian Perikanan Indonesia 20, 43 (2014)

41. E. Rahmat, Buletin Teknik Litkayasa Sumber Daya Dan Penangkapan 6, 29 (2016)

42. F.-C. Hsu, C. D. Elvidge, K. Baugh, M. Zhizhin, T. Ghosh, D. Kroodsma, A. Susanto, W. Budy, 
M. Riyanto, and R. Nurzeha, Remote Sensing 11, 995 (2019)

43. M. Doddema, G. Spaargaren, B. Wiryawan, and S. R. Bush, Fisheries Research 208, 49 (2018)

44. M. I. Marzuki, R. Garello, R. Fablet, V. Kerbaol, and P. Gaspar, in OCEANS 2015 - Genova (2015), pp. 1-5

45. E. Rodríguez-Marín, H. Arrizabalaga, M. Ortiz, C. Rodríguez-Cabello, G. Moreno, and L. T.
Kell, ICES Journal of Marine Science 60, 1216 (2003)

46. M. N. Maunder and A. E. Punt, Fisheries Research 70, 141 (2004)

47. A. F. Nelwan, M. Zainuddin, and M. Kurnia, Marine Fisheries: Journal of Marine Fisheries Technology and Management 6, 129 (2015) 